\title{
Pemberdayaan Masyarakat Berbasis Komunitas Melalui Usaha Mikro Kecil Menengah (UMKM) (Studi Kasus Kelompok Pembuat Kritcu BaBe di Desa Batu Belubang)
}

\author{
Tiara Ramadhani ${ }^{1}$ \\ Universitas Bangka Belitung
}

\begin{abstract}
Indonesia as a Unitary State in realizing national goals regardless of ethnicity, race, and religion. This means that the national goal covers all Indonesian people without exception. So here the Government which is the organizer and mobilizer in realizing the national goals must play an active and sustainable role to carry out national development. The implementation of development in Indonesia is basically a process of humanizing people faced by a number of multidimensional challenges. One of them is the problem of poverty. poverty is a problem that is never resolved from time to time. The national development is realized through economic development, which not only focuses on the physical condition of a region, but the community can participate in a development process that can improve economic welfare through the process of community empowerment. One form of community empowerment is community empowerment in Batu Belubang Village, Bangka Tengah Regency, which is carried out through a community of kritcu makers (processed seafood typical of Bangka Belitung). It is said that community-based community empowerment is that people become independent and can improve economic well-being, especially the economic well-being of their families. The research method used in this research is qualitative research method. This research aims to gain a deep understanding of the phenomena that occur in society. As for the type of qualitative research in this research is a case study. Data sources come from housewives as MSMEs and batu belubang village officials and articles sourced from newspapers and scientific journals. The results showed that MSME products from Batu Belubang Village run well and develop rapidly, as seen from the turnover obtained every month by each member of the group.
\end{abstract}

Keywords: Community Empowerment, Community, MSMEs

\begin{abstract}
Abstrak
Indonesia sebagai Negara Kesatuan dalam mewujudkan tujuan nasional tidak memandang Suku Bangsa, ras, dan agama. Artinya tujuan nasional melingkupi seluruh Rakyat Indonesia tanpa terkecuali. Sehingga disini Pemerintah yang merupakan penyelenggara dan penggerak dalam mewujudkan tujuan nasional tersebut harus berperan aktif dan berkesinambungan untuk melaksanakan pembangunan nasional. Pelaksanaan pembangunan di Indonesia pada hakekatnya adalah suatu proses memanusiakan manusia yang dihadapkan oleh sejumlah tantangan yang multidimensi. Salah satunya adalah permasalahan kemiskinan. kemiskinan adalah permasalahan yang tidak pernah ada penyelesaiannya dari waktu ke waktu. Pembangunan nasional tersebut diwujudkan melalui pembangunan ekonomi, yang tidak hanya memfokuskan pada kondisi fisik suatu wilayah,
\end{abstract}

${ }^{1}$ Tiaramadhani30@yahoo.co.id 
melainkan masyarakat dapat berpartisipasi dalam suatu proses pembangunan yang dapat meningkatkan kesejahteraan ekonomi melalui proses pemberdayaan masyarakat.

Salah satu bentuk pemberdayaan masyarakat yaitu pemberdayaan masyarakat di Desa Batu Belubang Kabupaten Bangka Tengah yang dilakukan melalui komunitas pembuat kritcu (makanan olahan hasil laut khas Bangka Belitung). Dikatakan sebagai sebuah pemberdayaan masyarakat berbasis komunitas adalah bahwa masyarakat menjadi mandiri dan dapat meningkatkan kesejahteraan ekonomi, terutama kesejahteraan ekonomi keluarga mereka. Metode penelitian yang digunakan dalam penelitian ini adalah metode penelitian kualitatif. Penelitian ini bermaksud untuk memperoleh pemahaman yang mendalam tentang fenomena yang terjadi di masyarakat. Sedangkan untuk jenis penelitian kualitatif dalam penelitian ini adalah studi kasus. Sumber data berasal dari ibu-ibu rumah tangga selaku pelaku UMKM dan aparat desa Batu Belubang dan artikel yang bersumber dari koran dan jurnal ilmiah. Hasil penelitian menunjukkan bahwa produk UMKM dari Desa Batu Belubang berjalan dengan baik dan berkembang dengan pesat, terlihat dari omset yang diperoleh setiap bulan oleh masing-masing anggota kelompok.

Kata Kunci : Pemberdayaan Masyarakat, Komunitas, UMKM

\section{Pendahuluan}

Berbicara mengenai kesejahteraan ekonomi, tidak terlepas dari pembangunan, baik itu pembangunan nasional maupun pembangunan ekonomi. Pembangunan pada dasarnya adalah suatu upaya yang bertujuan untuk mewujudkan tujuan nasional Bangsa Indonesia yang berasaskan maju, mandiri, sejahtera, berkeadilan dan berdasarkan iman dan takwa kepada Tuhan yang Maha Kuasa. Hal tersebut juga sejalan dengan makna yang terkandung dalam Pembukaan UUD 1945 yaitu hakekat dari suatu pembangunan nasional adalah untuk mencerdaskan kehidupan bangsa, menciptakan kesejahteraan umum, melindungi seluruh tumpah darah Indonesia dan membantu melaksanakan ketertiban dunia dan perdamaian abadi.

Indonesia sebagai Negara Kesatuan dalam mewujudkan tujuan nasional tidak memandang Suku Bangsa, ras, dan agama. Artinya tujuan nasional melingkupi seluruh Rakyat Indonesia tanpa terkecuali. Sehingga disini Pemerintah yang merupakan penyelenggara dan penggerak dalam mewujudkan tujuan nasional tersebut harus berperan aktif dan berkesinambungan untuk melaksanakan pembangunan nasional.

Pelaksanaan pembangunan di Indonesia pada hakekatnya adalah suatu proses memanusiakan manusia yang dihadapkan oleh sejumlah tantangan yang multidimensi. Salah satunya adalah permasalahan kemiskinan. kemiskinan adalah 
permasalahan yang tidak pernah ada penyelesaiannya dari waktu ke waktu. Sehingga menjadi pertanyaan, sebenarnya apa yang menjadi akar permasalahan dari kemiskinan dan factor-faktor apa yang dominan dibalik permasalahan kemiskinan. salah satu cara Pemerintah yang hingga saat ini masih terus dilakukan adalah dengan melaksanakan Pembangunan yang dilaksanakan secara terencana dan berkesinambungan yang hasil dari proses pembangunan tersebut dinikmati oleh seluruh Rakyat Indonesia secara adil dan merata. Pembangunan nasional tersebut diwujudkan melalui pembangunan ekonomi, yang tidak hanya memfokuskan pada kondisi fisik suatu wilayah, melainkan masyarakat dapat berpartisipasi dalam suatu proses pembangunan yang dapat meningkatkan kesejahteraan ekonomi melalui proses pemberdayaan masyarakat.

Pemberdayaan merupakan salah satu cara Pemerintah dalam mewujudkan tujuan nasional dan menjaga stabilitas ekonomi. Berbicara mengenai pemberdayaan, tidak terlepas dari peran masyarakat yang dalam hal ini sebagai perencana, pengorganisasi, pengimplementasi, dan pengawasan jalanya proses dan program pemberdayaan. Keberhasilan suatu proses pemberdayaan masyarakat dilihat dari kemandirian masyarakat baik itu memikirkan, memutuskan sampai melakukan pemberdayaan. Suatu masyarakat dikatakan berdaya, apabila kelompok masyarakat tersebut terlepas dari perangkap kemiskinan dan keterbelakangan, dalam artian, masyarakat memiliki akses untu system sumber, penguasaan teknologi, kepemilikan modal, serta sumber-sumber informasi. Dengan proses pemberdayaan, akan menciptakan sebuah masyarakat yang lebih siap untuk menghadapi kondisi apapun tanpa mengharapkan pertolongan dan bantuan dari Pemerintah.

Salah satu bentuk pemberdayaan masyarakat yaitu pemberdayaan masyarakat di Desa Batu Belubang Kabupaten Bangka Tengah yang dilakukan melalui komunitas pembuat kritcu (makanan olahan hasil laut khas Bangka Belitung). Dikatakan sebagai sebuah pemberdayaan masyarakat berbasis komunitas adalah bahwa masyarakat menjadi mandiri dan dapat meningkatkan kesejahteraan ekonomi, terutama kesejahteraan ekonomi keluarga mereka. Pemberdayaang berbasis komunitas adalah sebuah langkah yang nyata bagi masyarakat itu sendiri 
untuk memenuhi kebutuhan mereka. Hal tersebut dikarenakan bahwa masyarakat secara tidak langsung dapat memberdayakan diri mereka sendiri tanpa tekanan atau intervensi dari pihak lain. Dengan kata lain, bahwa pemberdayaan berbasis komunitas lebih mengedepankan pada kearifan lokal yang menunjukkan identitas dari masyarakat itu sendiri

Pemberdayaan berbasis komunitas dalam hal ini adalah melalui UMKM pembuat kritcu BaBe, dengan alasan bahwa UMKM dapat menjadi wadah bagi sekelompok masyarakat untuk dapat mengembangkan diri dan kemampuan mereka agar dapat menghasilkan sesuatu yang dapat memberikan manfaat tidak hanya bagi diri mereka sendiri tetapi juga bagi banyak orang, selain itu, melalui UMKM juga masyarakat lebih leluasa dalam mengembangkan hasil produk dan memasarkan hasil produk karena biasanya ketika sebuah produk dipasarkan melalui UMKM akan lebih dapat dipercaya oleh konsumen. Selain itu juga, melalui UMKM diharapkan masyarakat dapat mengembangkan jaringan dengan UMKM luar yang lebih sukses misalnya melalui kegiatan studi banding, pelatihan, dll.

Kelompok pembuat "kritcu BaBe" sudah berjalan lama dan sudah memasarkan hasil penjualan produknya hingga luar Bangka Belitung. Selain itu, mandirinya kelompok ini adalah bahwa mulai dari pengolahan, pengemasan hingga pemasaran dilakukan sendiri oleh kelompok mereka di Desa Batu Belubang, dengan memanfaatkan sumber daya yang tersedia di Desa mereka, sehingga mereka tidak perlu mengeluarkan biaya tambahan. Penghasilan yang diperoleh oleh kelompok ini dalam satu bulan mencapai satu jutaan (Rp.1.000.000,-) per anggota kelompok, sehingga jika ditotal dengan jumlah anggota kelompok yang terdiri 5-7 orang, penghasilan bersih tiap bulan kelompok pembuat "kritcu BaBe" bisa mencapai 7-8 jutaan. Dari hasil pembuatan kritcu yang sudah memiliki label "kritcu BaBe" tersebut, yang dalam hal ini adalah para ibu-ibu rumah tangga, mereka dapat mengisi waktu luang dan menghasilkan pendapatan.

Hal ini juga senada dengan yang dikatakan oleh Kepala Desa Batu Belubang, "alhamdulillah bu, disini kelompok pembuat 'kritcu BaBe' ini sudah mandiri dan besar omzet mereka tiap bulannya. Dalam sebulan itu, masing-masing anggota kelompok bisa mendapatkan satu juta perbulan. Bisa dibayangkan berapa 
total omset kelompok perbulannya. Mulai dari pengolahan, hingga pengemasan produk mereka kerjakan sendiri”.

Hal inilah yang menjadi ketertarikan penulis untuk melihat pemberdayaan masyarakat berbasis komunitas melalui usaha mikro kecil menengah (UMKM) dengan studi pada kelompok pembuat "kritcu BaBe" di Desa Batu Belubang Kabupaten Bangka Tengah. Jika ditinjau dari aspek sosiologis, bahwa pemberdayaan masyarakat berbasis komunitas melalui UMKM kritcu BaBe ini memiliki ciri khas sendiri yang tidak dimiliki oleh UMKM lain, yaitu mereka mengedepankan kearifan lokal mereka sendiri, mulai dari bahan baku pembuatan kritcu, sumber daya manusia dalam pembuatan kritcu, hingga cita rasa dari kritcu tersebut juga menjadi ciri khas tersendiri bagi konsumen.

\section{Pemberdayaan Masyarakat}

Konsep pemberdayaan menurut Ife dalam Edi Suharto, bahwa pemberdayaan memiliki dua pengertian yaitu kekuasaan dan kelompok lemah. Kekuasaan yang dimaksud disini adalah kekuasaan atas :

a. Pilihan personal dan kemampuan dalam membuat keputusan mengenai gaya hidup, tempat tinggal dan pekerjaan.

b. Pendefinisian kebutuhan : kemampuan individu dalam menentukan kebutuhan selaras dengan keinginannya.

c. Ide atau gagasan : kemampuan masyarakat dalam menentukan kebutuhan sesuai dengan keinginannya.

d. Lembaga : kemampuan masyarakat dalam menjangkau, menggunakan dan mempengaruhi pranata masyarakat, misalnya kesejahteraan social, Pendidikan dan kesehatan.

e. Sumber-sumber : kemampuan masyarakat dalam memobilisasi sumber baik formal maupun kemasyarakatan.

f. Aktivitas ekonomi : kemampuan masyarakat dalam memanfaatkan dan mengelola produksi, distribusi dan pertukaran barang serta jasa.

g. Reproduksi : kemampuan masyarakat dalam kaitannya dengan kelahiran, perawatan anak, Pendidikan dan sosialisasi. 
Sehingga disini pemberdayaan dapat dikatakan sebagai sebuah proses dan tujuan. Sebagai proses, pemberdayaan merupakan serangkaian kegiatan yang dilakukan untuk memperkuat kekuasaan dan keberdayaan kelompok lemah. Sedangkan pemberdayaan sebagai sebuah tujuan, merupakan tolak ukur pemberdayaan sebagai sebuah proses.

Berbicara mengenai pemberdayaan, mengacu pada Kieffer (1981) dalam Edi Suharto, pemberdayaan mencakup tiga dimensi dengan beberapa indicator keberdayaan :

a. Kebebasan mobilitas.

b. Kemampuan membeli komoditas kecil.

c. Kemampuan membeli komoditas besar.

d. Terlibat dalam pembuatan keputusan rumah tangga.

e. Kebebasan relative dari dominasi keluarga.

f. Kesadaran huku dan politik.

g. Keterlibatan dalam kampanye dan protes.

h. Jaminan ekonomi dan kontribusi terhadap keluarga.

Strategi pemberdayaan dapat dilakukan melalui beberapa aras diantaranya adalah aras mikro, aras mezzo dan aras makro. Dimana masing-masing aras memiliki pendekatan masing-masing yang berfokus sesuai dengan strategi pemberdayaan. Aras mikro yang dapat dilakukan dengan pendekatan yang berpusat pada tugas, aras mezzo, yang dapat dilakukan dengan strategi meningkatkan kesadaran seperti pelatihan sedangkan aras makro, dapat dilakukan dengan menggunakan pendekatan perumusan kebijakan, perencanaan social, aksi social dan lain sebagainya. Sedangkan untuk pendekatan yang dapat dilaksanakan, diantaranya adalah : pemungkinan, penguatan, perlindungan, penyokongan dan pemeliharaan.

\section{Komunitas}

Terdapat beberapa definisi tentang komunitas, diantaranya menurut McMillan dan Chavis (1986) mengutip dari comdev.binus.ac.id, komunitas adalah kumpulan dari para anggotanya yang memiliki rasa saling memiliki, terikat diantara satu dan lainnya dan percaya bahwa kebutuhan para anggota akan dapat terpenuhi selama para anggota berkomitmen untuk terus Bersama-sama. Sedangkan menurut 
Hillery, George (1955) dalam comdev.binus.ac.id, komunitas adalah hal yang dibangun dengan fisik atau lokasi geografi dan kesamaan dasar akan kesukaan dan kebutuhan. Sehingga disini dapat disimpulkan, komunitas adalah sekelompok orang yang berada dalam satu wilayah, yang memiliki rasa memiliki, saling terikat satu sama lain yang didasari atas kebutuhan dan keinginannya.

\section{Usaha Mikro Kecil Menengah (UMKM)}

Menurut Undang-Undang Nomor 20 Tahun 2008 tentang Usaha Mikro, Kecil dan Menengah terbagi kedalam beberapa pengertian diantaranya :

a. Usaha mikro adalah usaha produktif milik orang perorangan dan/atau badan usaha perorangan yang memenuhi kriteria usaha mikro sebagaimana diatur dalam Undang-Undang.

b. Usaha kecil adalah usaha ekonomi produktif yang berdiri sendiri, yang dilakukan oleh orang perorangan atau badan usaha yang bukan merupakan anak perusahaan atau cabang perusahaan yang dimiliki, dikuasai, atau menjadi bagian baik langsung maupun tidak langsung dengan badan usaha kecil atau badan usaha besar dengan jumlah kekayaan bersih atau hasil penjualan tahunan yang sudah diatur dalam perundangan.

c. Usaha menengah adalah usaha ekonomi produktif yang berdiri sendiri, yang dapat dilakukan oleh orang perorangan atau badan usaha yang bukan merupakan anak perusahaan atau cabang perusahaan yang dimiliki, dikuasai atau menjadi bagian baik langsung maupun tidak langsung dnegan usaha kecil.

Sehingga dapat disimpulkan bahwa usaha mikro kecil dan menengah (UMKM) adalah usaha produktif yang dimiliki oleh orang/perorangan, badan usaha, berdiri sendiri yang memiliki kekayaan bersih atau hasil penjualan tahunan sesuai dengan yang diatur dalam undang-undang yang berasaskan ; kekeluargaan, demokrasi ekonomi, kebersamaan, efisiensi berkeadilan, berkelanjutan, berwawasan lingkungan, kemandirian, keseimbangan kemajuan serta kesatuan ekonomi nasional. Pada hakekatnya tujuan dari UMKM adalah untuk menumbuhkan dan mengembangkan usahanya dalam rangka membangun perekonomian nasional yang berdasarkan ekonomi berkeadilan. 


\section{Metode Penelitian}

Metode penelitian yang digunakan dalam penelitian ini adalah metode penelitian kualitatif. Penelitian ini bermaksud untuk memperoleh pemahaman yang mendalam tentang fenomena yang terjadi di masyarakat. Sedangkan untuk jenis penelitian kualitatif dalam penelitian ini adalah studi kasus yaitu penelitian yang mendalam tentang individu, satu kelompok satu organisasi, satu program kegiatan dan lain sebagainya dalam waktu tertentu. Sumber data dalam penelitian adalah terdiri dari sumber data primer dan sumber data sekunder. Sumber data primer yang dimaksud adalah pelaku usaha UMKM yaitu ibu-ibu rumah tangga pembuat kritcu BaBe dan Pemerintah Desa Batu Belubang. Sedangkan untuk data sekunder terdiri dari data-data yang diperoleh dari koran, data dari kantor desa, dan jurnal ilmiah yang berkaitan dengan informasi yang ingin diperoleh. Sedangkan untuk metode pengumpulan data yang digunakan dalam penelitian ini adalah menggunakan metode wawancara dan observasi langsung. Wawancara dilakukan secara langsung kepada ibu-ibu rumah tangga selaku pelaku UMKM dan aparat Pemerintah Desa Batu Belubang dan observasi dilakukan langsung ke lokasi pembuatan kritcu BaBe.

\section{Hasil dan Pembahasan}

Hasil dari penelitian ini menunjukkan bahwa kelompok usaha kecil mikro dan menengah (UMKM) desa Batu Belubang berjalan dengan lancar dan berkembang dengan pesat. Hal tersebut terlihat dari meningkatnya permintaan produksi untuk kritcu $\mathrm{BaBe}$, meningkatnya penghasilan ibu-ibu rumah tangga pelaku UMKM dengan penghasilan bersih tiap bulan sebesar Rp. 1.000.000,- untuk masing-masing anggota kelompok. Selain itu juga, penjualan kritcu BaBe sudah dikenal banyak kalangan masyarakat dan sudah dikirim ke luar Bangka Belitung. Hal ini menunjukkan bahwa tidak hanya masyarakat Desa Batu Belubang yang mengenal produk UMKM tersebut, tetapi masyarakat luar Bangka Belitung juga mengenal produk UMKM yang dijual dengan harga Rp.120.000,-/bungkus tersebut.

Produk UMKM tersebut merupakan hasil olahan laut dari cumi yang dijadikan makanan sejenis kripik yang proses pembuatan, pengolahan, hingga pengemasan dilakukan oleh kelompok ibu-ibu tersebut, hingga mereka 
mendapatkan BPOM produk tersebut dilakukan sendiri. Hal ini menunjukkan kemandirian dan keberdayaan kelompok tersebut sudah bisa dikatakan cukup dan memadai. Hasil penjualan dari produk UMKM mereka juga cukup untuk memenuhi kebutuhan hidup mereka sehari-hari dan terlihat dari rumah-rumah permanen di wilayah Desa Batu Belubang yang menggambarkan bahwa walaupun dengan pekerjaan sebagai nelayan dan pembuat kritcu, mereka dapat memenuhi kebutuhan hidup mereka sehari-hari dan kebutuhan sampingan lainnya.

Pemberdayaan masyarakat berbasis komunitas melalui UMKM kritcu BaBe ini sudah dikenal oleh banyak orang dan dapat meningkatkan penghasilan masyarakat itu sendiri. Walaupun pada dasarnya belum pesat perkembangannya, tetapi jika dilihat dari lamanya UMKM tersebut berdiri, maka dapat dikatakan bahwa UMKM kritcu BaBe sudah dapat menunjukkan eksistensi mereka di kalangan UMKM lainnya. Yang tidak kalah menarik adalah bahwa UMKM kritcu BaBe ini mengandalkan kearifan lokal yang dalam hal ini baik itu untuk SDM dan bahan baku pembuatan kritcu itu sendiri, mereka tidak perlu mengeluarkan modal yang cukup besar.

Selain itu, hasil dari penelitian ini juga menggambarkan bahwa proses pemberdayaan masyarakat yang dilakukan sudah baik dan berjalan sesuai dengan sebagaimana seharusnya. Masyarakat yang semula berawal dari dari bantuan dana desa, tidak menjadikan mereka ketergantungan terhadap bantuan dari Pemerintah. Tetapi, malah sebaliknya, dimana membuat mereka mandiri yang dibekali dengan pelatihan dari Disperindag Kabupaten Bangka Tengah.

\section{Kesimpulan}

Pelaksanaan pembangunan di Indonesia pada hakekatnya adalah suatu proses memanusiakan manusia yang dihadapkan oleh sejumlah tantangan yang multidimensi. Salah satunya adalah permasalahan kemiskinan. kemiskinan adalah permasalahan yang tidak pernah ada penyelesaiannya dari waktu ke waktu. salah satu cara Pemerintah yang hingga saat ini masih terus dilakukan adalah dengan melaksanakan Pembangunan yang dilaksanakan secara terencana dan berkesinambungan yang hasil dari proses pembangunan tersebut dinikmati oleh 
seluruh Rakyat Indonesia secara adil dan merata. Pembangunan nasional tersebut diwujudkan melalui pembangunan ekonomi melalui proses pemberdayaan masyarakat.

Berbicara mengenai pemberdayaan, tidak terlepas dari peran masyarakat yang dalam hal ini sebagai perencana, pengorganisasi, pengimplementasi, dan pengawasan jalanya proses dan program pemberdayaan. Keberhasilan suatu proses pemberdayaan masyarakat dilihat dari kemandirian masyarakat baik itu memikirkan, memutuskan sampai melakukan pemberdayaan. Dengan proses pemberdayaan, akan menciptakan sebuah masyarakat yang lebih siap untuk menghadapi kondisi apapun tanpa mengharapkan pertolongan dan bantuan dari Pemerintah.

Salah satu bentuk pemberdayaan masyarakat yaitu pemberdayaan masyarakat di Desa Batu Belubang Kabupaten Bangka Tengah yang dilakukan melalui komunitas pembuat kritcu (makanan olahan hasil laut khas Bangka Belitung). Dikatakan sebagai sebuah pemberdayaan masyarakat berbasis komunitas adalah bahwa masyarakat menjadi mandiri dan dapat meningkatkan kesejahteraan ekonomi, terutama kesejahteraan ekonomi keluarga mereka. Dari hasil pembuatan kritcu yang sudah memiliki label "kritcu BaBe" tersebut, yang dalam hal ini adalah para ibu-ibu rumah tangga, mereka dapat mengisi waktu luang dan menghasilkan pendapatan.

Hasil dari penelitian menunjukkan bahwa kelompok usaha kecil mikro dan menengah (UMKM) desa Batu Belubang berjalan dengan lancer dan berkembang dengan pesat. Hal tersebut terlihat dari meningkatnya permintaan produksi untuk kritcu $\mathrm{BaBe}$, meningkatnya penghasilan ibu-ibu rumah tangga pelaku UMKM dengan penghasilan bersih tiap bulan sebesar Rp. 1.000.000,- untuk masing-masing anggota kelompok 
Pemberdayaan Masyarakat Berbasis Komunitas Melalui Usaha Mikro Kecil Menengah (UMKM) (Studi Kasus Kelompok Pembuat Kritcu BaBe di Desa Batu Belubang)

\section{Daftar Pustaka}

https://Comdev.binus.ac.id.

https://Gurupendidikan.co.id.

https://id.m.wikipedia.org.

Ife, Jim. Community Development : Alternatif Pengembangan Masyarakat di Era

Ojk.go.id.

Globalisasi. Yogyakarta: Pustaka Pelajar

Prayitno, Singgih. 2010. Pembangunan Sosial : Wacana, Implementasi, dan Pengalaman Empirik. Jakarta: Pusat Pengkajian Pengolahan Data dan Informasi (P3DI)

Suharto, Edi. 2010. Membangun Masyarakat, Memberdayakan Rakyat : Kajian Strategis Pembangunan Kesejahteraan Sosial dan Pekerjaan Sosial. Bandung: Refika Aditama

Uin-malang.ac.id. 